Compression Wood in Gymnosperms (in three volumes). T.E. Timell, SpringerVerlag, New York, 2150 p., 1986. US\$398.00, ISBN 0-387-15715-8.

This three volume treatise on compression wood should contain something of interest to anyone involved in forestry or the utilization of wood.

The first volume answers the question "What is compression wood?" It includes information on the history, identification, structure, chemistry, physical properties, origin, and formation of compression wood. Volume two covers the occurrence of compression wood in stems, branches, and roots; factors that lead to compression wood formation; and the physiology of and inheritance of compression wood. The third volume has chapters on ecology, silviculture, and the function of compression wood, as well as its importance in the lumber and the pulp and paper industries, the induction of compression wood by the balsam woolly aphid, and, finally, the properties of opposite wood.

The structure of the text allows the reader to find information on a desired topic rather easily. Each chapter is organized as an independent review of a particular subject area. Although there is ample cross referencing, there is also a fair amount of repetition from chapter to chapter. In some texts, repetition may be considered a negative feature but the size of this work makes it essential and allows the chapters to flow without forcing the reader to constantly flip back and forth to find points made several hundred pages earlier or in another volume. Each volume contains a table of contents for the entire set. In addition, there is a detailed table of contents at the beginning of each chapter. A gymnosperm species index and a 147 page subject index are also included. Each chapter begins with a general introduction and ends with general conclusions. The text of the chapters is divided into sections and subsections in a logical manner and each section has its own introduction and conclusions. Readers with a specific interest are able to satisfy that interest without reading the entire text or even an entire chapter. Although it is likely that many readers will find individual chapters interesting enough to finish once they have satisfied their curiosity about a specific area, it is unlikely that many will want to read the entire treatise.

The comprehensive nature of the reviews (over 8100 references) allows the reader a certain degree of confidence that all published information on a topic is covered regardless of the language in which it was written. Minor reviews of related topics are scattered through the text where they contribute to the overall understanding of compression wood. For example, chapter 4 contains good reviews of tracheid length distribution in trees as well as of microfibril angle in normal wood. Chapter 7 includes considerable information on variation of relative density in stems lacking compression wood, and chapter 15 contains detailed information on the modes of attack of trees by insects. Almost every chapter includes similar "mini reviews".

Readers of The Forestry Chronicle will probably find volumes two and three of most interest in their work, but volume one will be useful for background information. Even with the massive amount of material presented in these volumes, it is clear that compression wood is still not completely understood. Unfortunately, much of the missing information would be of particular interest to forest managers or tree breeders. For example, almost nothing is known about the heritability of compression wood in stems without defects. This fact makes chapter 14 on the inheritance of compression wood rather disappointing. For those interested in silviculture (chapters 10,11 and 16), there is still no clear answer to the question of how much lean is acceptable in crop trees.

While the size and cost of this work make it unlikely that it will be included in many personal libraries or used as a required text in teaching, it is an invaluable addition to university, industrial and government libraries. Appropriate chapters should be seriously considered as required reading for students of wood technology, materials science, silviculture, entomology, and forest genetics. Researchers in these areas would also benefit from taking a careful look at this excellent reference work.

\section{Jamie Barbour}

Forintek Canada Corp.

Ottawa

Growing Exotic Forests. Bruce J. Zobel, Gerrit Van Wyk and Per Stahl, WileyInterscience, New York, 508 p., 1987, US\$57.50, ISBN 0471-80915-2.

Exotic forests of "trees that are growing in an area in which they do not naturally occur" are by no mean confined to the tropics. Stands of Sitka spruce in Scotland are no less exotic than are tracts of teak in Trinidad and Tobago. However, exotic forestry is of particular interest because it is the most likely key to saving the tropical forest resource from destruction. This is reason enough to look with great interest at a textbook that sets out "to organize and summarize some of the information currently available on exotic forestry" and also to present "personal observations and concepts of the authors, based upon many years of working with exotics in several areas throughout the world". While the growing of exotics in warm climates is emphasized in Growing Exotic Forests, exotic forestry in temperate and boreal regions ("where exotic forestry began") is incorporated into the general picture.

The authors state emphatically that "there is no greater area of misinformation and ignorance in forestry than in the field of exotic forestry". Though other contenders for this dubious distinction may spring to mind, the authors may well be right. In any event, Growing Exotic Forests has been written as both a textbook for schools and universities and a reference for those already, about to be, or might become involved in exotic forestry.

There are 10 chapters: Exotics, general concepts; Species, varieties and geographical variation; Genetic improvement; Limitations of and unusual problems with exotic forests; Seed production, seed certification, vegetative propagation, and monoculture; Exotics in warm climates: Exotics in temperate climates; Gene conservation: Wood properties; and Political and associated biological problems. An appended list of "some of the more important acronyms related to exotic forestry" includes abbreviations as well as acronyms but omits many that might have been included (e.g., CDC, CIDA, CSRO DTC, ECA, IBED, IBRD, IDA, IFC, ILO, IUCN, OAU, ODI, STRC, WHO, WMO, and UNESCO); and their "location" could have been expanded usefully to give mailing addresses rather than merely the name of the country. There are more than 70 pages of references, a species index that lacks authorities for the scientific names, and a less than adequate subject index. Several of the photographic figures have not reproduced well, though in Fig. 4.1, at least, the impact is not impaired; this figure shows a Brazilian plantation of an (unidentified) exotic $30 \mathrm{~m}$ tall 5 years after planting!

Perhaps the statement made by the authors (in relation to exotic forestry) that "It is especially difficult to differentiate among tropical, subtropical, and temperate [areas]" will raise some eyebrows. By this, however, all that is meant is that tree species do not always observe the niceties of human climatic classification systems when responding to the environments into which they have been introduced. The many special combinations, particularly of site and introduced provenance, are difficult to fit into a rigorous definition. The authors repeatedly emphasize the importance of provenance and of studying and protecting the source of exotic material in its indigenous habitat. Provenance differences within the natural range of a species usually become more evident outside of that range. This theme is maintained throughout the book. 
In spite of some flaws, which can readily be corrected in a second edition, Growing Exotic Forests largely achieves the authors' objectives. A very large literature is surveyed and presented in a well organized fashion that facilitates follow-up to original sources. And the reader is left in no doubt as to either the most dangerous pitfalls or the most promising opportunities.

\section{R.F. Sutton}

Agroforestry: Realities, Possibilities and Potentials. H.L. Gholz (Ed.), Nijhoff, Dordrecht, The Netherlands, 227 p.., 1987. US\$68.00, ISBN 90-247-3590-4; also available in paperback, ISBN 90-2473591-2. Distributor in Canada and U.S. Kluwer Academic, Hingham, MA, USA 02018-0358

Agroforestry has been defined as "a collective word for all land-use practices and systems in which woody perennials are deliberately grown on the same land management unit as annual crops and/or animals". Some range scientists would substitute "agricultural" for "annual" in that definition and thereby exclude "silvopastoral" (the grazing of natural forage under natural tree cover, i.e., forest grazing) and "agro-pastoral" (trees absent) practices. In any event, agroforestry covers a lot of territory, much of it imperfectly charted. Hence the value of this collection of 12 papers, which stems from a series of seminars presented at the University of Florida by leading authorities from Nigeria, Kenya, Nepal, Brazil, Peru, Costa Rica, California, Florida, and Hawaii.

Few Canadian foresters might be expected to know much about or have great interest in "taungya", "swiddenfields", "living fences", or even plantations of palm trees, yet many would be enthralled by the accounts of these and other agroforestry matters in this book. The descriptions and discussions are well written and highly informative, a reflection of both the astuteness of Professor Gholz in the selection of contributors and his editorial expertise.

The insight offered into this diverse aspect of forestry is of particular relevance to the tropics. Since the tropical moist forests and their treasures, many of them undreamed of, are in imminent danger of being obliterated, any knowledge that increases the ability of man to use these forests without destroying them is valuable indeed. Agroforestry and the resurgence of interest in the concept is one of the more hopeful signs for the future.

\section{R.F. Sutton}

Forest Soils and Nutrient Cycles. P.M. Attiwill and G.W. Leeper, Melbourne University Press, Melbourne, Victoria, 202 p., 1987 . US\$29.95 + \$2.25 postage and handling, ISBN 0-522-84315-8.
Exclusive distributor in Canada and USA: ISBS Specialized Book Services, Inc.), 5602 NE Hassalo St., Portland, Oregon 79213, USA.

Authored by two distinguished scientists, (Dr. Attiwill is Reader in Botany at the University of Melbourne; and, at the same University, the second author was Emeritus Professor of Agricultural Chemistry until he died just before the book was published) this book discusses nutrients and nutrient cycling in Australian forest soils. An exhaustive treatise on forest soils has not been attempted. Citations from the literature have been used sparingly but effectively. Much of the text comes directly out of the authors' own research. The writing is clear and unpretentious.

The result is a good, straightforward text on forest soils and the movement of nutrients between soils and plants. The text is valuable in more than the Australian context. Neither the domination of the Australian forest flora by 500 or more species of Eucalyptus and 830 or more species of Acacia, nor the occurrence of ancient landscapes with multiple cycles of erosion, obscure the principles involved. The perspectives presented by data drawn from research mainly in the more productive native eucalypt forests and the exotic pine plantations offer illuminating insights into causes and effects. At the same time, the authors do not gloss over problems, deficiencies and enigmas; this, too, is a strength.

After the Introduction, there are 11 chapters: Physics and colloid chemistry of soil; Organic matter; Nitrogen; Phosphorus in Australian forest soils; Sulphur, trace elements, and others; Cycles and burials: Soil profiles and soil maps, Forests of Australia; Growth of a forest; Cycles of nutrients in forests; and Fire and forests. The species index lacks botanical authorities. The subject index, in conjunction with the excellent table of contents, is adequate.

Forest Soils and Nutrient Cycles was written during the teaching of plant ecology to final-year students in botany and forestry. It will be useful to anyone interested in the interrelationships between soils and plants.

\section{R.F. Sutton}

Plantation Silviculture in Temperate Regions, with special reference to the British Isles. Peter S. Savill and Julian Evans, Clarendon Press, Oxford Scientific Publications, 246 pp., 1986, \$68.75, ISBN 0-19-854138-4

Plantation Silviculture is organized into four parts: A. Introduction; B. Principles of Plantation Silviculture; C. Specialized Forms of Plantation Silviculture; and D. Protection and Plantation Layout.

The three chapters that constitute Part A deal with such matters as the role of plantations, primary production and longterm productivity, and climate and site, including site classifications for use in silviculture, and terrain classifications. Key terms are defined. Part A serves its purpose admirably, presenting a broad and illuminating view of plantation silviculture in general.

Part B forms the main body of the book. There are six chapters: Drainage and cultivation: Selection of species; Plantation establishment; Weed control; Nutrition; and Spacing, thinning, pruning, and rotation length. Emphasis is on coniferous plantations for industrial wood production The authors note that forest nurseries are not considered in detail "because, in temperate regions at least, these are increasingly the province of specialized nursery managers rather than foresters" The omission is unfortunate. Many of the problems in plantation silviculture have arisen precisely because of such dichotomy between nursery and field. The linkage must be strengthened, and it is a disservice to plantation silviculture to neglect any opportunity for so doing Separation of nursery and field responsibilities not only inhibits feedback from field to nursery but also interposes a no-man's land of ill defined responsibility between shipping and planting

Rehabilitative plantings, short-rotation crops, and plantations for shelter, sport. exudates, Christmas trees, ornamental foliage, bark, and food are covered in the 30 pages of $P$ art $C$. The depth of treatment is necessarily shallow, and some of the topics, e.g., plantations on derelict land are poorly supported by specific references. Citation of texts and reviews would have been useful.

Part D is a brief overview of protection from pests, wind, and fire together with a final chapter on the layout of plantation forests.

To be successful, a book intended as "an introduction to plantation silviculture for undergraduate and postgraduate students in forestry and related fields' must avoid both the Scylla of not saying enough and the Charybdis of saying too much. For the most part, Savill and Evans have managed to steer safely between these dangers. Information is presented clearly and is mostly well referenced to provide adequate leads for further exploration of the literature. If they have erred, it is on the side of not saying enough about certain matters of more than average importance.

Topics that with advantage might have been discussed in greater depth include the influence of spacing, irrigation, nutrition, photoperiod, carbon dioxide enrichment, wrenching, and root pruning, in the nursery on subsequent performance in the field. These and other matters, such as the thigmonastic effects of handling, i.e., the damage inflicted on planting stock by mechanical banging, crushing, etc. may often be of decisive importance in the establishment of plantations. Discussion of methods available for evaluating the condition and performance potential of planting stock would also have been desirable. 
The good index includes the novel inclusion here, rather than in the text, of the authorities of the scientific names of plants and animals mentioned in the thereby uncluttered text. I noticed no typographical errors and but one editorial lapse, the heading of Table 6.1 proclaiming nutrient contents while the table reports concentrations. The book is produced in the elegant Oxford tradition.

\section{R.F. Sutton}

\section{Silvicultural and Management Prospects of Sustained Utilization}

François Mergen and Jeffrey R. Vincent (Ed.), Yale University School of Forestry and Environmental Studies, New Haven, 212 p., 1987

This short book comprises a set of symposium papers focused on the questions 'When is natural management of tropical moist forests (TMF) appropriate. and how can it be made effective and feasible?' The central problem is a conflict between, on the one hand, developmental concerns (i.e., the need in developing countries for a wide range of products from the forests for local use and export, as well as for land for agriculture and settlement), and, on the other hand, the extreme biological importance of these forests and their role in soil and water conservation and maintenance of environmental stability. The problem and the issues that stem from it gain prominence as the natural resources concerned are subjected to the unprecedented demands currently being placed upon them. The scope and depth of the biological, economic, political, and sociological analysis encompassed by the book, as well as its wide geographical coverage, render it a landmark publication.

The authors of the papers represent considerable international experience in tropical moist forest research, management, and development, particularly in Southeast Asia, West Africa, and Central America. According to the Introduction by Professor Mergen, their contributions were solicited for a symposium that was to assess critically what is known about management of natural TMF and to provide North American foresters with an opportunity to learn about the topics, particularly in relation to management for timber production.

The keynote paper is by John WyattSmith, a British tropical forester with experience spanning nearly 50 years. $\mathrm{He}$ examines problems (of which there are many) and prospects (which he rates mainly poor) for management of natural TMF. Artificial plantations and enrichment planting in selected areas are likely to prevail for industrial plantation needs. Natural TMF management should be applied to all other forest land. Success would depend not on technical but on political and social factors, including definition of forest policies within the framework of broad, integrated land use policies.

Problems and strategies for managing Malaysia's extensive, economically important Dipterocarp forests are discussed by Hon Tan Tang of the Sabah Foundation. He echoes the notion of intensive management of selected areas for timber production and extensive management of the remainder, at low cost, on a minimum intervention basis. West African foresters are less sanguine about natural TMF management. Philip Asabere reviews the history of management of Ghana's 8.2 million ha of TMF in which both the shelterwood system and enrichment planting have given such disappointing results that salvage felling of overmature trees is now in progress. He advocates reversion to selection felling on a 40-year cycle with greater use of less known species, higher stumpage rates, and plantation establishment as an adjunct to natural forest production. Concerning West Africa in general, L.C. Nwoboshi stresses pressures for land for purposes other than forestry, paucity of commercial species, costliness of assisting natural regeneration, and slow growth rates, as obstacles to economic management of TMF for timber production. He advocates plantations as the principal means of wood production, retaining natural forest as nature reserves and wildlife habitat as well as for watershed protection. Broadly similar conclusions are reached by P.R.O. Kio and S.A. Edwebelan in their review of the history of and obstacles to the management of TMF for sustained wood production in Nigeria.

Frank Wadsworth of the Institute of Tropical Forestry in Puerto Rico, in a lucid synopsis, points to broad similarities between the TMF of the New World, Africa, and Asia; these suggest that techniques developed in the latter should be applicable in the former, although only to selected, permanent TMF areas. Repeated felling damage under cyclic selection working jeopardizes future crops, pointing to the need for greater harvesting control than simply setting girth limits. Wadsworth, too, suggests that plantations will increasingly become the primary sources of wood.

All authors stress the need for research to augment the information base for TMF management. Ian D. Hutchinson advocates simple, low cost thinning techniques, for application where silvicultural factors permit, to increase economic production. He emphasizes the importance to success of adequate training and supervision. Michael Philip reviews obstacles to measuring growth and yield in TMF. He contends that data on these features and on regeneration, required for management, can be obtained from quite simple sequential measurements, based, however, on sophisticated sampling design and subjected to sophisticated analytical and modelling techniques.

In a refreshing paper on economic feasibility of natural TMF management, A.J. Leslie notes that political support for the activity is dependent largely on demonstration of the economic viability of such management. However, cost/benefit analysis undertaken to this end is often flawed, e.g., by: the use of financial rather than economic accounting; the paucity of good information; and the combination of slow growth rates and modest stumpage rates tipping the balance against natural TMF management through 'the burden of compound interest.' This tends to bias the analysis. Carefully conducted cost/ benefit analysis of low-intensity natural management, avoiding several pitfalls of such analysis, might yield more favourable results in many cases.

The conclusion to which the reader is led is that the problems of natural TMF management are great. Better knowledge of silviculture, technical management, and wood technology would be useful in solving them. However this would be a long way from being enough because the social, economic, and political dimensions of the overall problem are usually transcendent. The question whether and how much natural TMF management should be undertaken and supported in any specific instance requires resolution on the basis of an evaluation much wider than a technical one, implying expansion of the criteria normally used.

Publication of this book now is timely in view of the concerns being voiced, e.g., in the recently released report of the World Commission on Environment and Development, about the rate of depletion of TMF (estimates of which range from 20 to 50 ha per minute worldwide), about the inadequacy of control over much of what remains of it, about the declining productivity of second growth forests, and about the economic, environmental, and ecological effects of these trends.

F.B. Armitage Ottawa 